\title{
Ethnicity in motion? German language islands in Brazil and Russia
}

Peter Klaus Rosenberga

\begin{abstract}
Today, German language islands in Russia and Brazil are on the way to language shift. On this way, the varieties of these communities display certain features of decomposition and simplification in terms of morphology. Regular and irregular morphology, however, are developing differently: while case reduction is the main characteristic of regular noun inflection, in personal pronouns case distinctions are maintained. Results are presented from a research project about language change in case morphology of German language islands with 125 speakers living in close contact to the majority populations in Brazil and Russia. The core idea of the project is the assumption that we can learn as well from language obsolescence as from language emergence which has been the subject of linguistic research in the past. Through its comparative perspective, it seems possible to account for internally or externally induced linguistic change. Language decay is apparently not just disorder, not amorphous, but somehow structured. Certain lexical classes are more subject to reduction than others, and some residual features retain morphological "core" functions (in terms of case semantics). Language change is accelerated in times of blurring sociolinguistic differences and fading linguistic norms as an implication of losing ethnic boundaries. The recent co-officialization of minority languages in Brazil might slow down these processes. In a transcultural approach, teaching of Pomeranian as minority language (alongside the national language) could stabilize the local linguistic community, building a bridge to the High German standard language, and even to English as a lingua franca of international communication.
\end{abstract}

Keywords: Language islands. Language contact. Language change. Language revitalization.

Recebido em 25 de janeiro de 2017 Aceito em 26 de abril de 2017

a Professor do Departamento de Linguística da Europa Universität Viadrina. E-mail: rosenberg@europa-uni.de 
The very existence of language islands is related to boundary marking. They depend on their distinctiveness. Language islands are distinct linguistic communities within a limited area; they have tight networks and an awareness of their distinctiveness, which marks a certain difference from the surrounding linguistic community. Conversely, if the boundary vanishes, the island is swept away by the floods: their inhabitants are assimilated into the majority society, adopting the contact language.

In Brazil and in Russia we are today concerned with a linguistic fate of German language islands "in the flood". That is why we must ask: What makes the construction of ethnic boundaries stable and what makes it unstable?

Let us have a look at a case of obsolescence (DORIAN, 1989) of language islands, a process which starts with some degree of boundary diffusion, and ends with language shift. At the present moment, we observe a period of language change induced by intense language contact, but structured by language internal processes. That is what is occurring in some language islands in Russia and Brazil today.

In the following section, an empirical observation of linguistic simplification and change will be presented. Afterwards, some sociolinguistic explanations on boundary marking will be discussed. And, finally, we will come to some conclusions concerning ethnic revitalization in Brazil.

\section{Language islands in the flood}

Our research is done among language islands in the area of Pelotas, Rio Grande do Sul, Southern Brazil, with the East Low German Pomeranian and the West Central German Hunsrück varieties, and in the Altai region in West Siberia, Russia, with the West Upper German Katholisch and the East Low German Plautdietsch varieties. 125 speakers of three agegroups (younger than 40 years, $40-59$, older than 60 years) have been recorded, 61 in Russia (27 speakers of Plautdietsch, 34 of "Katholisch") and 64 in Brazil (39 speakers of Pomerano, 25 of Hunsrückisch). Since the data has been collected one half each in the 1990s and in the 2000s (until 2011) it was possible to include 16 recordings of the same speakers after 10-13 years. 
The goal of our research is to study language use in German-speaking communities with some degree of disintegration of the speech community, which leads to morphological simplification in the form of case reduction. Our credo is that this story of language decomposition just as well as language composition - tells us something about the structure of language since the process is not at all amorphous or chaotic.

We compare two language islands each in Brazil and Russia (High German and Low German varieties), with speakers living in close contact with the majority population. The persecutions of the past have resulted in decreasing numbers among the speech communities, and the liberalizations that followed have diminished their distinctiveness and led to a process of assimilation, especially among the younger generations.

1.1. Some findings about linguistic change in the language islands in Russia and Brazil

Linguistically, we observe - like in other countries - case reduction in regular morphology, but case maintenance in irregular morphology. Just a few examples will be given to illustrate case marking after dative input in a translation task where speakers were asked to translate standard German input into the language island dialect.

Reduction of case morphology to -(e) $n$ or $-e$ (or $-\varnothing)$ is very frequent in noun inflection. As the following examples show especially dative is subject to reduction:

(1) ick hefflöcher in mine schoine strömp ('Ich habe Löcher in meinen schönen Strümpfen' - I've got holes in my nice stockings)

(2) an maine noas hengt'n dropp ('An meiner Nase hängt ein Tropfen' - A drop hangs from my nose.)

(3) dei hoor op minen kopp sin grau. ('Die Haare auf meinem Kopf sind grau' - The hairs on my head are grey.) 
The use of $d e n /-n$ as a default for all kinds of oblique case marking is common and well attested, even for neuter:

(4) mi braure hett den schååp gråås jejeft ('Mein Bruder hat dem Schaf Gras gegeben' - My brother has given grass to the sheep.)

(5) den letste jåar (,das letzte Jahr' - the last year)

(6) wi derfe in den hus rinnegåån (,Wir dürfen in das Haus hineingehen' - we may go into the house)

What is shown in Fig. 1 is case distinction in regular morphology (noun inflection: nouns, determiners, adjectives, demonstrative and possessive pronouns):

Figure 1. Regular morphology (noun inflection): Realization of dative input. (Translation task, 125 speakers, $n=6218$, percent)

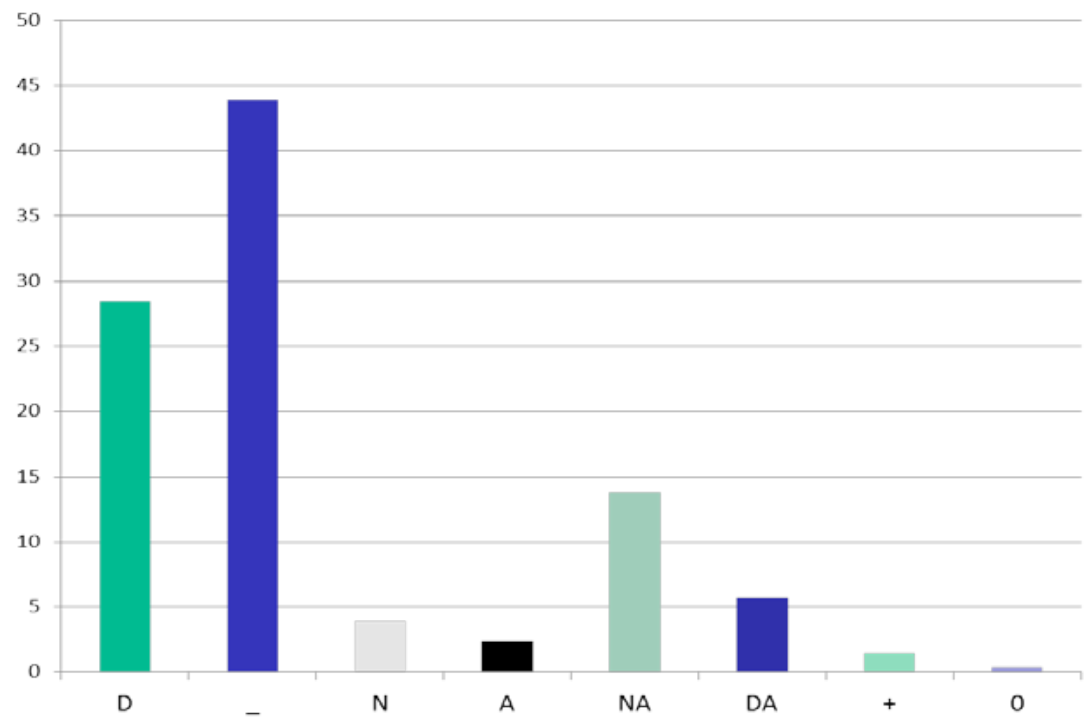

[ $\mathrm{D}=$ dative realization, $=$ no case ending (for instance $d e), \mathrm{N}=$ nominative, $\mathrm{A}=$ accusative $\mathrm{NA}=$ common form for nominative and accusative (die), DA = common form for dative and accusative (euch), $+=$ additional form, $0=$ no realization $]$.

It is obvious that less than one third of the dative input is translated into dative output. 
Fig. 2 and 3 compare case marking in adjectives on dative and accusative input. Both figures are very similar: dative and accusative are realized with the same endings: a predominant common case (NA). Case marking is vanishing in noun inflection of the language islands observed.

Figure 2. Adjective inflection: Realization of dative input. (Translation task, 125 speakers, $\mathrm{n}=699$ )

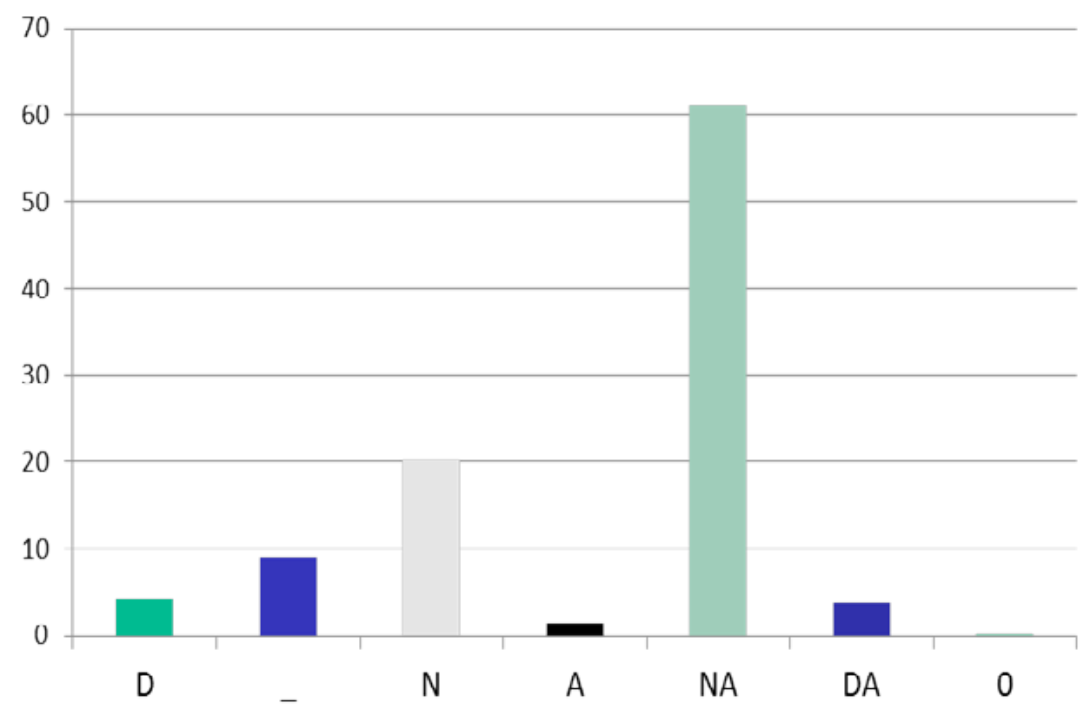

Figure 3. Adjective inflection: realization of accusative input. (Translation task, 125 speakers, $\mathrm{n}=766$ )

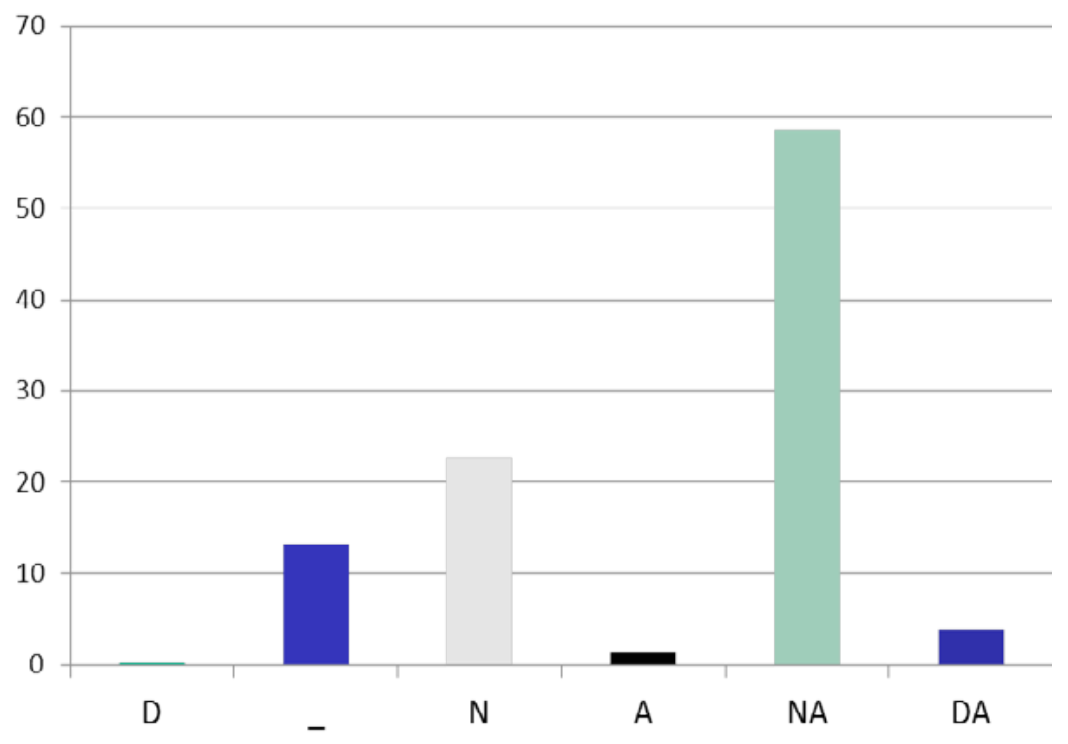


The examples (1) - (6) given above are taken from Low German speakers, but the same structure is found in all recordings of all varieties in both countries with only small differences as fig. 4 reveals:

Figure 4. Adjective inflection by varieties: Realization of dative input $(n=699)$

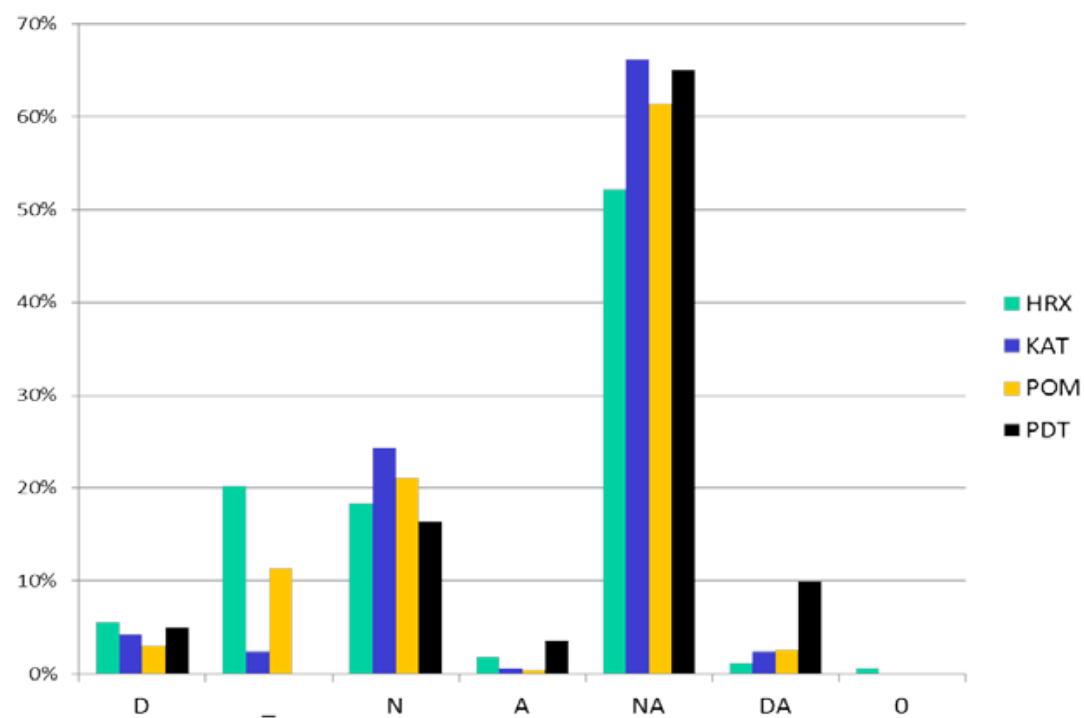

${ }^{1}$ The high proportion of DA (oblique case marking) is represented mostly by the Low German personal pronouns $m i$ or $d i$ for standard German 'mir/ mich' ('me') or 'dir/dich' ('you', singular).

[HRX = Hunsrückisch, KAT = "Katholisch", POM = Pomerano, PDT $=$ Plautdietsch]

While dative is only rarely realized in noun inflection it is very frequent in personal pronoun inflection. A clear difference with about two thirds of the data realizing dative output is presented in Fig. 5: ${ }^{1}$ 
Figure 5. Irregular morphology (personal pronoun inflection): Realization of dative input. (Translation task, 125 speakers, $\mathrm{n}=986$ )

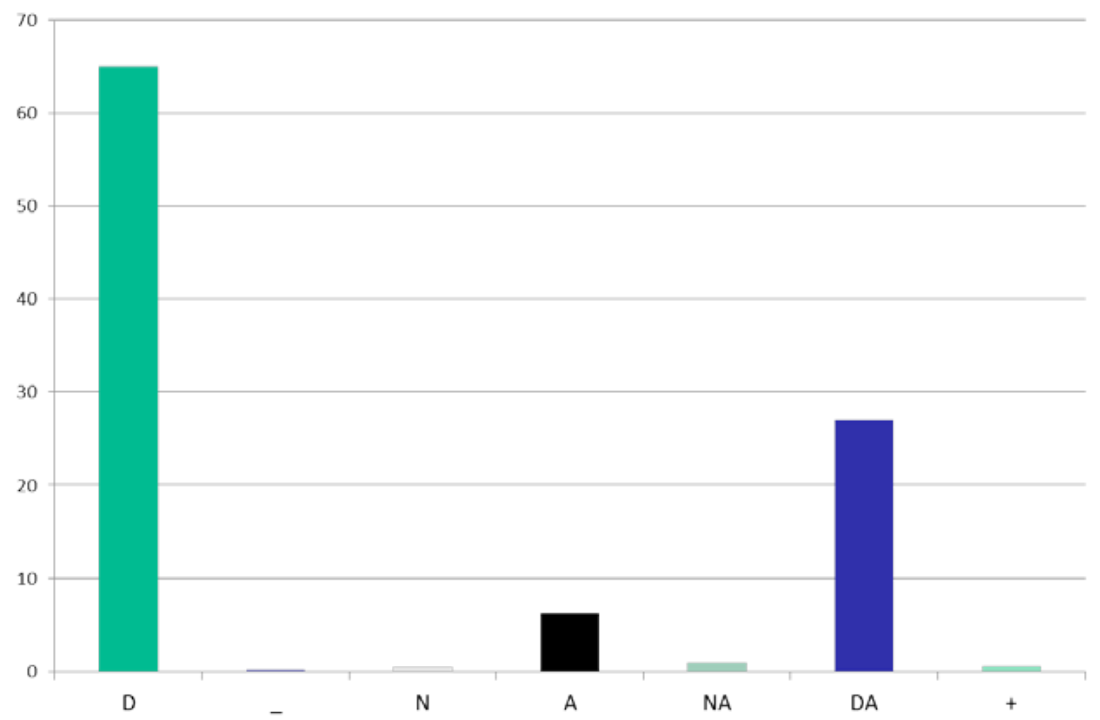

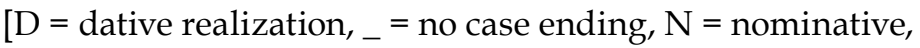
$\mathrm{A}=$ accusative, $\mathrm{NA}=$ common form for nominative and accusative (sie),

$\mathrm{DA}=$ common form for dative and accusative $($ euch $)$, $+=$ additional form, $0=$ no realization] 
The use of dative pronouns is most frequent in personal pronouns of $3^{\text {rd }}$ person singular as is illustrated in Fig. 6:

Figure 6. Irregular morphology (personal pronoun inflection): Realization of case (Standard German dative) in $1^{\text {st }}, 2^{\text {nd }}, 3^{\text {rd }}$ person singular pronouns. (Interview and narration task, 125 speakers, $\mathrm{n}=412$ )

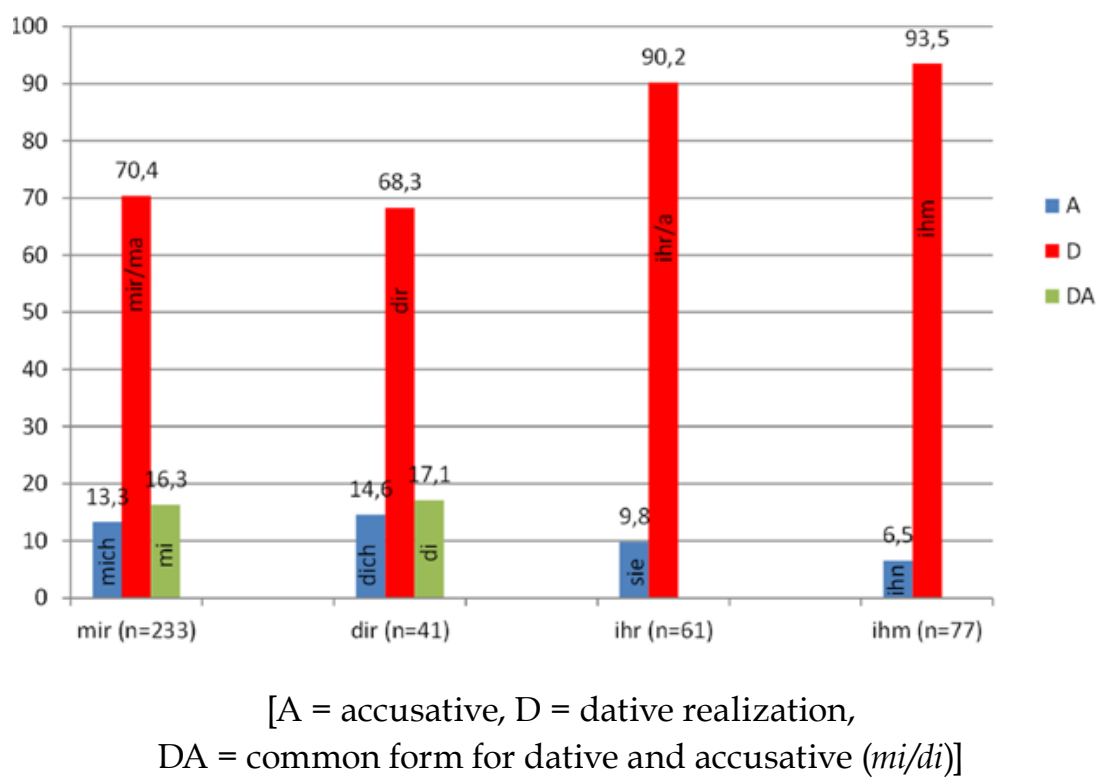

However, speakers often change the class of the word in their output when replacing personal pronouns (ihm, ihr 'him, her') with demonstrative pronouns (dem, der 'this.DAT'), and then use the accusative (den, die 'this.AKK'), which they frequently do when case-marking regular forms (Fig. 7). This is most frequent in the Brazilian colonies, with only about one half using dative and the other half replacing it with a common case or accusative (the Hunsrück speakers even more than the Pomeranians): 
Figure 7. Irregular morphology (personal pronoun inflection): Case marking in personal pronouns (on dative input) realized as demonstrative or indefinite pronouns (per cent). (Translation task, 125 speakers, $\mathrm{n}=298$ )

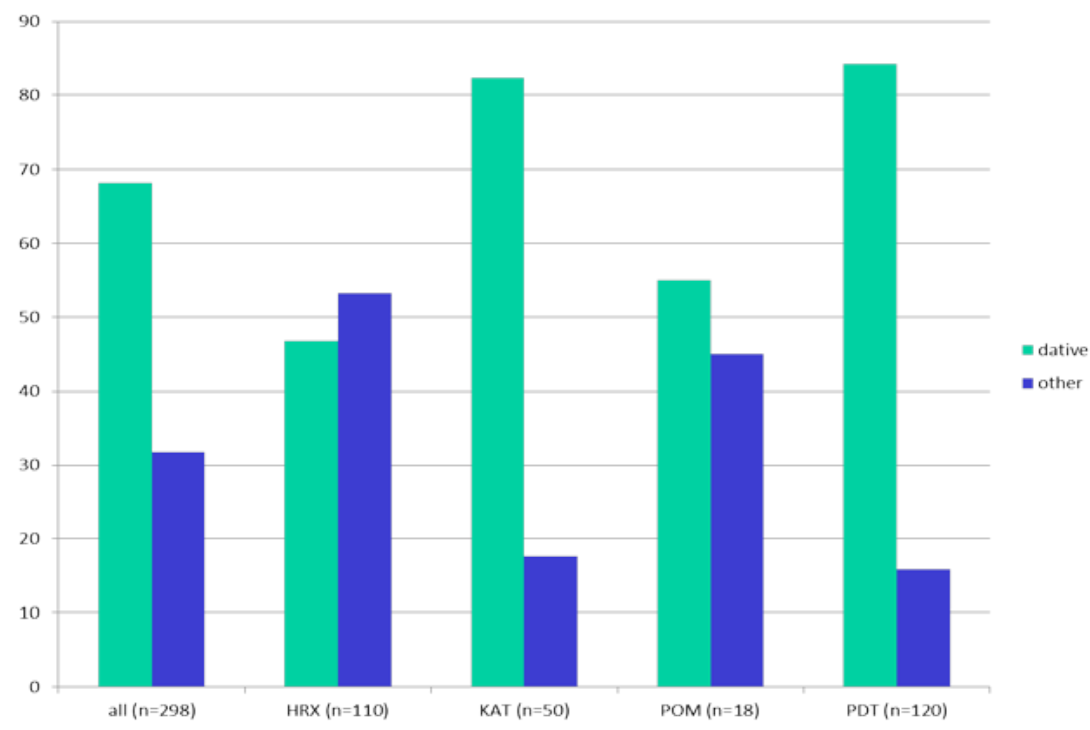

$[$ HRX $=$ Hunsrückisch, KAT = "Katholisch", POM = Pomerano, PDT $=$ Plautdietsch]

\subsection{Accelerated, but ordinary change}

These changes emerge in all varieties observed, not only in those communities with intense contact to the majority language or to another German variety. That is why convergence is not very likely to serve as an explanation of this kind of change. Case reduction occurs in communities with a morphologically "rich" contact language (Russian), as well as with a "poor" one (Brazilian Portuguese), in morphologically more "conservative" varieties (Low German dialects), as well as in others (High German dialects). Of course, there are some differences - Low German dialects are morphologically more "stable" - but the varieties share the same tendencies.

Hence, the case reduction presented above appears to be an accelerated - but ordinary - linguistic change all German varieties are subject to, not essentially a matter of contactinduced adoption or convergence. While in irregular inflection, 
the case system is rather stable, regular case morphology is radically simplified: the outcome is a reduction of case marking endings to $-(e) n /-e$, which represents the German weak noun inflection system expanded even to the strong inflection paradigm. Frequently, there is no longer any case marking.

Personal pronouns reveal more case distinction for different reasons (cf. SALMONS, 1994, p. 64; ROSENBERG, 2016), the most important being their high frequency, their animate referents, their "full listing" mental representation as monomorphemic words and words with irregular word formation (cf. CHOLEWA, 1993).

The reduction of grammatical distinctions in the language islands observed could be interpreted as a kind of degrammaticalization which, however, is structured by case semantics: dative is maintained with personal pronouns in its "core function" (cf. JAKOBSON, 1936) as the case of the animate receiver.

But what might be the sociolinguistic explanation of the acceleration of change?

\subsection{The sociolinguistics of change}

Change in the Brazilian language islands is more intense, but the Russian language islands catch up quickly. The process of assimilation began earlier in the Brazilian German communities, but it is more rapid in the Russian German communities.

The Brazilian society is multiethnic and the German speaking minority is only one of a hundred ethnic communities. From the beginning, the German colonists have been "aliens" by mission: for about 100 years, they kept their distance to the surrounding population in terms of geography, language, culture, economy, religion and social structure. Since about 1940 "Brazilianization" has emerged, unifying the country (at least in what concerns "white" Brazilians), in the last decades modernizing the society, and, hence, lowering the barriers of social contact. For a long time, the maintenance of the minority language and culture depended on the autonomous settlement. The German speaking settlements, however, became subsequently integrated into the society. Today, the 
Brazilian Germans in our colonies are primarily Brazilians, speaking Brazilian Portuguese, married with Brazilians of other ethnic descent, studying somewhere in the country. Among the younger ones, the German language has become a heritage language. The disintegration of the language islands has begun two generations ago. Nowadays, ethnic diversity is a familiar trait of all people but it is not a vital resource of social distinction.

The former USSR was - by constitution as well as by societal awareness - based on ethnicity. Experience was matched by this kind of ethnic framing. Language served as a boundary marker since it represented a difference: the experience of communicative belonging (as long as "compact groups" were demarcated by language and code alternation structures were established) as well as of social or cultural difference. This was even true in the deportation camps and guarded villages.

German settlement in the USSR has always been discontinuous. The manifold migrations (voluntarily or not) of the Russian Germans have not affected the ethnically based belonging. However, the construction of "central villages" with different German varieties spoken enhanced the expansion of Russian among the younger generation: a former study (ROSENBERG, 2002) in a Siberian village revealed that for intergroup communication Russian has displaced German, but not for intragroup conversation. In intragroup communication Mennonites, for instance, used exclusively German to a degree of about $60 \%$, in intergroup communication of only $20 \%$.

Since the breakdown of the Soviet Union, a disruptive language shift emerged among Russian Germans because of the mass emigration of resettlers ("Aussiedler") to Germany in the 1990s. Today, the majority language is dramatically expanding in public and private domains. Younger generations are quickly shifting to Russian, code-mixing is more frequent than code-switching, and the proportion of second-language learners outweighs native speakers. Intermarriage is steadily increasing, and getting vocational education outside of the village is common. Additionally, the ethnic composition of the villages is becoming more diffuse because of the replacement of the emigrated resettlers by non-Germans or non-regionals 
(immigrating Germans from the Central Asian republics of former USSR). Today, only about $15 \%$ of the villagers are locally born and network clusters are dissolving. Being German is not a primary distinction anymore.

Some traits of an accelerated disintegration of the Russian German language islands can be detected from our sociolinguistic background information as far as language is concerned:

If asked whether the speakers use the contact language (Russian or Brazilian Portuguese) with their parents (Fig. 8), more Russian Germans predominantly answer not at all (more than Brazilian Germans). But with their children, Russian Germans use Russian only or frequently by a clear majority (Fig. 9):

Figure 8. Family domain of language usage: Speaking contact language with parents in Brazil and Russia $(n=60)^{2}$

2 The 60 respondents are only the speakers interviewed in the 2000s.

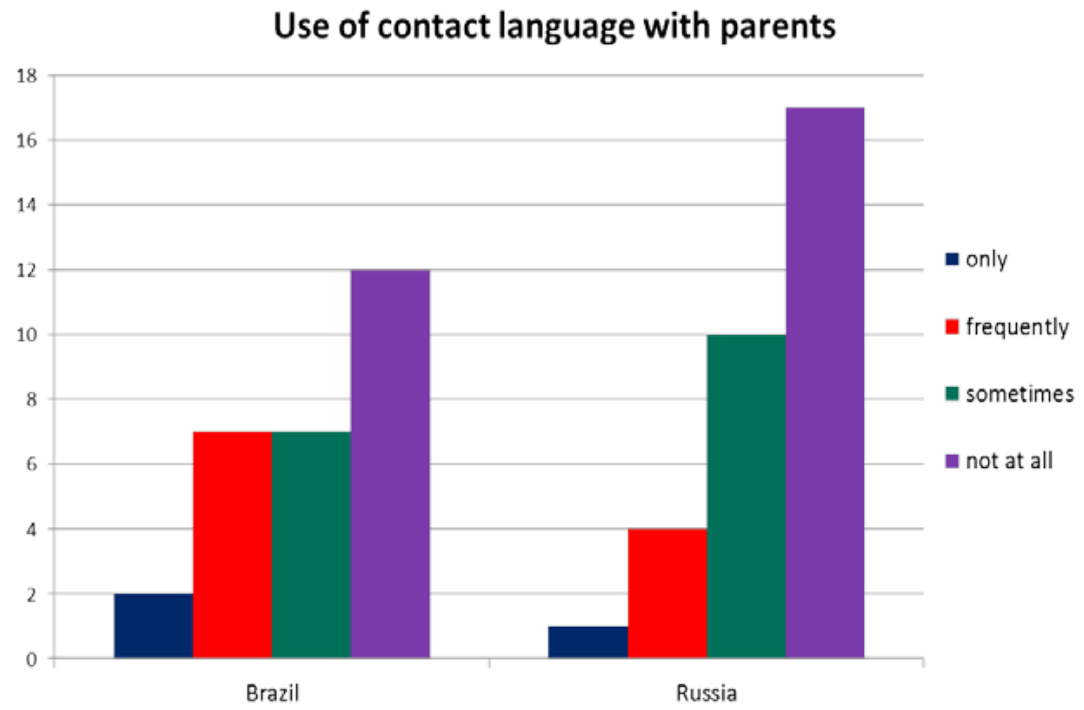


Figure 9. Family domain of language usage: Speaking contact language with oldest child in Brazil and Russia $(n=54)$

Use of contact language with oldest child

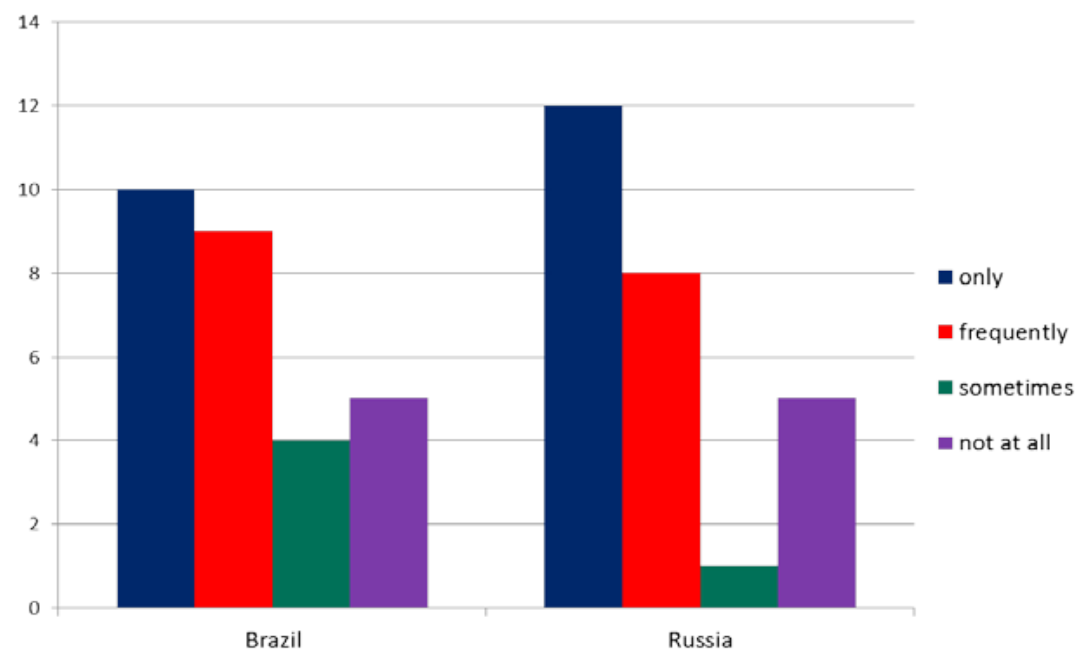

At work, Russian Germans use Russian most frequently, which was not the case in former times, when almost $100 \%$ of the villagers were of German descent (Fig. 10):

Figure 10. Public domain of language usage: Speaking contact language at work in Brazil and Russia $(n=61)$

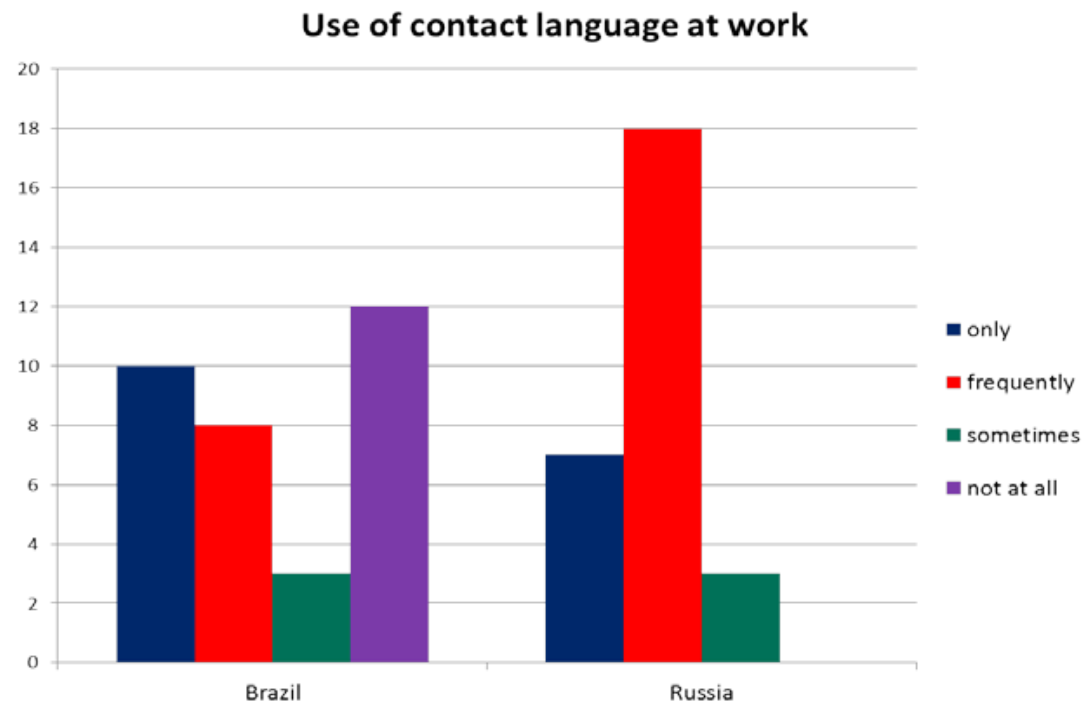


What is striking in our findings is that the acceleration in language change in the Russian-German language islands is not simply a consequence of language contact and imposition. What we find is a loss of something different: the gradual loss of knowing and caring about what is linguistically "ours" and what is "theirs". This is connected to a lack of intergenerational transmission of the German language, an increasing proportion of non-native speakers, a common practice of code-mixing (frequently without any awareness of using elements of two languages). The determining factor which might have opened the gate for change in these communities could be called a loss of "normativity", i.e. of norm awareness and norm loyalty. And this brings about the problem of boundary marking and the (linguistic) resources to construct boundaries.

\section{The socio-cultural background: the diffusion of boundaries}

Ethnic boundaries are not "given" by the essence of origin, language or culture, but constructed by choice and evaluation of social relations.

How can ethnic boundaries be constructed?

Instead of disregarding the role of experience and culture, I would suggest taking construction as a threefold process of selection of experiential features (making them "focused" in terms of LE PAGE/TABOURET-KELLER, 1985), their hierarchization (making them relevant) and - as far as attitudes are involved - their evaluation (making them highly valued).

However, in the language islands presented above, linguistic distinctions lose their boundary-marking function. Thus, we must ask: under which circumstances does language serve as an ethnic boundary marker, under which does it lose this ability?

The answer is a threefold, too: language is an ethnic boundary marker if it serves a communicative need (in some language domains), if it displays a certain distinctiveness, and if it is considered a legitimate distinction within an ethnic frame, i.e. if social experience is reasonably focused as an ethnic structure with prototypical actors of relevant "ethnic" characteristics. 
In the language islands presented above, normativity decreases and ethnic borders become diffuse - interestingly not in times when oppression is most severe, but when language and culture lose their discreteness. Then, the disintegration of the linguistic community is the consequence. Losing boundaries is akin to losing norm awareness, norm institutions and norm loyalty, which opens the gate for obsolescence and simplification. Mattheier (1998, p. 834) drew attention to the conditions of the fading of norms: (a) the degree of target norm awareness, (b) the degree of norm codification, (c) the degree of norm tolerance, (d) the perceived difference between in-group and outgroup norm.

This is what we observe in these language islands losing their distinctiveness generation by generation: The norm awareness is diffusing among younger speakers (condition a), it is not codified like all dialects, not even in relation to a German diasystem (b). Most important, second language learners gain ground without any corrections by fully competent speakers (c), and constant code-mixing blurs linguistic differences (d). Thus, fading linguistic norms may lead to losing ethnic boundaries.

Inevitably?

\section{Perspectives: Ethnicity and transnationalization}

This is the point where the efforts of ProEPo and other projects of language revitalization come into play: the revitalization of Pomerano, of Hunsrück, of Talian, of Nhengatu and the other minority languages marks a most important and quite disruptive cut within the Brazilian minority and ethnic politics. The institutional support of the minority languages by co-officialization, especially by school instruction might prove to be the best way to win social recognition. And, of course, this is overdue in a multiethnic and "globalizing" state like Brazil.

However, it seems not appropriate and not promising just to aim at a bare renaissance of ethnicity and to dream back into the $19^{\text {th }}$ century.

People with German as spoken or heritage language are first of all Brazilians. In modern societies, the great unifiers - state, market and democracy - loosen ethnic boundaries, which is, of course, now also the fate of our language islands 
in "inundation". Thus, there is no way of establishing selfsufficient German national schools because the families will not be interested into ethnic separation.

And people are living in a globalized world. The younger ones have their facebook friends and their contacts abroad, and they are exposed to English. Their virtual social space is a transnational one and they adopt (trans)cultural traits from everywhere. Even if they intend to study in Europe (at an apprenticeship or at a university), it will not go without saying that these young people will study in Germany.

Teaching the minority language (as first or second language) must not at all be contradictory to teaching the national language - and not to English as a foreign language. Within a framework of intercomprehensive language learning (DOYÉ, 2005), teaching the local variety (like Pomerano) from the first years of schooling (parallel to Brazilian Portuguese) could build a bridge to the High German standard language (with the third year). And German could be a bridge to English as English is a (morphologically simpler) Germanic language. A command of German will help for learning English and it will not compete against Portuguese. The languages are not in a "zero-sum situation" but in a win-win situation if they are not based on isolationist but on multilingual and transcultural conceptions. In this sense, ProEPo and the other minority projects can be extremely helpful in preserving heritage culture and language in a modern society.

\section{REFERENCES}

CHOLEWA, J. Störungen der lexikalisch-morphologischen Wortverarbeitung bei Aphasie: Ein Literaturüberblick. Neurolinguistik, v. 7, n. 2, p. 105-126, 1993.

DORIAN, N. Introduction. In: DORIAN, N. (ed.) Investigating obsolescence. Studies in language contraction and death. Cambridge etc.: Cambridge University Press, 1989. p. p. 1-10 DOYÉ, P. Intercomprehension. Guide for the development of language education policies in Europe: from linguistic diversity to plurilingual education. Reference study. Strasbourg: Language Policy Division. DG IV - Directorate of School, Outof-School and Higher Education of the Council of Europe, 2005. 
JAKOBSON, R. Beitrag zur allgemeinen Kasuslehre. Gesamtbedeutungen der russischen Kasus. In: Travaux du Cercle Linguistique de Prague v. 6: Études Dédiées au Quatrième Congrès de Linguistes, Prague 1936. Praha: Jednota Československých Matematiku a Fysiku; Leipzig: Harassowitz, 1936. p. 240-288.

LE PAGE, R. B.; TABOURET-KELLER, A. Acts of Identity. Creolebased approaches to language and ethnicity. Cambridge etc.: Cambridge University Press, 1985.

MATTHEIER, K. J. Allgemeine Aspekte einer Theorie des Sprachwandels. In: BESCH, W. et al. (eds.) Sprachgeschichte. Ein Handbuch zur Geschichte der deutschen Sprache und ihrer Erforschung. 2nd ed. (Handbücher zur Sprach- und Kommunikationswissenschaft. 2.1). Berlin, New York: de Gruyter, 1998. p. p. 824-836.

ROSENBERG, P. Comparative speech island research: Some results from studies in Russia and Brazil. In: KEEL, W.; MATTHEIER, K. J. (eds.) German Language Varieties Worldwide: Internal and External Perspectives. Frankfurt (Main): Peter Lang, 2002. p. 199-238.

Regularität und Irregularität in der Kasusmorphologie deutscher Sprachinselvarietäten (Russland, Brasilien). In: KÖPCKE, K.-M.; BITTNER, A. (eds.): Regularität und Irregularität in Phonologie und Morphologie. Berlin, New York: de Gruyter (Linguistik - Impulse und Tendenzen), 2016. p. 177-217.

SALMONS, J. Naturalness and Morphological Change in Texas German. In: BEREND, N.; MATTHEIER, K. J. (eds.): Sprachinselforschung. Eine Gedenkschrift für Hugo Jedig. Frankfurt (Main): Lang, 1994. p. 59-72. 


\section{Resumo \\ Etnicidade em movimento? Ilhas linguísticas germânicas no Brasil e na Rússia}

As ilhas linguísticas existentes hoje na Rússia e no Brasil estão em processo de substituição. Desse modo, as variedades dessas comunidades apresentam certos traços de decomposição e simplificação no âmbito morfológico. No entanto, morfologias regular e irregular estão se desenvolvendo de modo diferente: enquanto a redução de caso é a maior característica da flexão nominal regular, as distinções de pronomes pessoais de caso são mantidas. Os resultados apresentados foram obtidos por meio de um projeto de pesquisa sobre mudança linguística em morfologia de caso de ilhas linguísticas germânicas, realizado com 125 falantes que vivem em estreito contato com as populações majoritárias do Brasil e da Rússia. A ideia central deste projeto é a suposição de que podemos aprender tanto com a obsolescência quanto com a emergência linguísticas, que já foram temas de pesquisas linguísticas no passado. Por meio de uma perspectiva comparativa, parece possível descrever mudanças linguísticas internamente ou externamente induzidas. Decadência linguística é, aparentemente, não só desordenada, não só amorfa, mas, de algum modo, estruturada. Certas classes lexicais são mais sujeitas à redução do que outras, e alguns traços residuais retêm funções morfológicas "centrais" (em termos de semântica de caso). A mudança linguística é acelerada em tempos de diferenças difusas e de enfraquecimento das normas linguísticas, como implicação de perda de fronteiras étnicas. A recente co-oficialização de línguas minoritárias no Brasil pode desacelerar esses processos. Em uma abordagem transcultural, o ensino do pomerano como língua minoritária (ao lado da língua nacional) poderia estabilizar a comunidade linguística local, construindo uma ponte para a variedade padrão do alemão e, até mesmo, para o inglês como língua franca de comunicação internacional.

Palavras-chave: Ilhas linguísticas. Contato linguístico. Mudança linguística. Revitalização linguísticas. 